\title{
PEMANFAATAN LIMBAH IRON SLAG SEBAGAI MATERIAL PENGGANTI SEBAGIAN PASIR PADA PRODUKSI BETON
}

\author{
Hijriah $^{1}$, Nur Hadijah Yunianti ${ }^{2}$ \\ Prodi Teknik Sipil Universitas Bosowa ${ }^{1,2}$ \\ E-mail : hijriah_civil@ymail.com¹, nurhadijahyunianti@gmail.com²
}

\begin{abstract}
ABSTRAK
Penggunaan produk baja sebagai bagian dalam struktur bangunan untuk konstruksi dalam negri semakin meningkat. Salah satu dampak operasional industry peleburan logam baja adalah besarnya jumlah limbah yang berupa slag yang dihasilkannya. Hal ini disebakan oleh kandungan logam didalam biji yang relatif kecil. Apabila slag yang dihasilkan tidak dikelola dengan baik, maka akan dapat menimbulkan masalah bagi lingkungan, sehingga slag perlu mendapatkan penanganan yang tepat. Inovasi pembuatan beton dengan penggunaan limbah, masih akan terus dikembangkan. Salah satu inovasi yang dilakukan adalah dengan memanfaatkan Iron slag sebagai bahan substitusi sebagian agregat halus. Penelitian ini bertujuan untuk mengetahui bagaimana kekuatan beton setelah menggunakan bahan tersebut.

Penelitian dilaksanakan di Laboratorium Struktur dan Bahan Beton Jurusan Teknik Sipil Universitas Bosowa. Benda uji dibuat dalam 2 (dua) tipe yaitu beton normal (beton kontrol) dan beton variasi Iron slag. Iron slag digunakan sebagai material substitusi agregat halus dengan memvariasikan kadarnya dalam campuran beton sebesar $0 \%, 75 \%$ dan $100 \%$ dan penggunaan Superplasticizer sebanyak 1\%. Benda uji akan diamati pada umur 28 hari, dimana jumlah benda uji sebanyak 29 buah. Data yang terkumpul digunakan untuk menganalisis karakteristik beton yang menggunakan Iron slag. Dari hasil penelitian disimpulkan bahwa peningkatan kuat tekan beton variasi yang tertinggi terjadi pada benda uji BS 100 yaitu sebesar sebesar 63,34\% terhadap beton normal (beton kontrol). Penggunaan Iron slag sebagai material pengganti sebagian agregat halus pada campuran beton dapat meningkatkan kemampuan beton dalam menahan beban.
\end{abstract}

Kata Kunci : Iron Slag, Substitusi Pasir.

\section{PENDAHULUAN}

Proses peleburan bijih nikel menghasilkan limbah berupa terak yang jumlahnya sangat besar. Terak tersebut harus ditangani atau dimanfaatkan dengan benar karena berpotensi menimbulkan masalah lingkungan serta fenomena sosial di masyarakat. Dengan demikian diharapkan dapat mengurangi efek pencemaran yang ditimbulkan dan juga dapat memberikan nilai ekonomis bagi terak tersebut.
Iron slag merupakan hasil residu pembakaran tanur tinggi, yang dihasilkan oleh industri peleburan baja. Limbah slag secara fisik menyerupai agregat kasar. Seiring dengan semangat pelestarian lingkungan, maka perusahaan penghasil limbah slag mencari solusi pemanfaatan limbah tersebut. Berdasarkan penelitian sebelumnya slag dapat dimanfaatkan sebagai agregat kasar dan agregat halus dalam bahan konstruksi dan campuran perkerasan aspal.

Berbagai penelitian dan percobaan telah dilakukan untuk meningkatkan 
kualitas beton itu sendiri. Menurut Hanif (2012) pabrik baja telah mengembangkan penggunaan iron slag sebagai bahan campuran untuk beton struktural agar dapat mengurangi biaya pembangunan atau perbaikan kembali terhadap sarana dan prasarana yang ada. Sehingga diharapkan iron slag memiliki nilai ekonomis tinggi selain itu dampak negatif akibat adanya iron slag terhadap kerusakan lingkungan dapat diminimalisir, sehingga lingkungan menjadi bersih, bebas dari limbah padat dan tetap terpelihara.

Dalam penelitian ini, penulis akan mengidentifikasi Pengaruh Pemanfaatan Limbah Iron Slag Sebagai Material Pengganti Sebagian Pasir pada Produksi Beton. Penulis berharap penelitian ini dapat memberikan wawasan/pengetahuan baru bagi akademisi/masyarakat mengenai solusi alternatif material yang dapat digunakan sebagai bahan ganti dalam memproduksi beton.

\section{TINJAUAN PUSTAKA}

\section{Pengertian Beton}

Dalam bidang bangunan yang dimaksud dengan beton adalah campuran dari agregat halus dan agregat kasar (pasir, kerikil, batu pecah atau jenis agregat lain) dengan semen yang dipersatukan oleh air dalam perbandingan tertentu. Beton juga dapat didefinisikan sebagai bahan bangunan dan konstruksi yang sifat-sifatnya dapat ditentukan terlebih dahulu dengan mengadakan perencanaan dan pengawasan yang teliti terhadap bahanbahan yang dipilih.

Beton diperoleh dengan mencampurkan material semen, agregat halus, agregat kasar, air dan kadang kadang ditambah dengan material lain. Untuk mendapatkan kualitas beton yang baik harus memperhatikan materialmaterial pembentuknya dan komposisinya. Tidak saja kualitas material yang baik akan tetapi juga diperhatikan mengenai keseragaman secara keseluruhan.

Parameter - parameter yang paling mempengaruhi kekuatan beton adalah:

1. Kualitas semen

2. Proporsi semen terhadap campuran,

3. Kekuatan dan kebersihan agregat,

4. Interaksi atau adhesi antara pasta semen dengan agregat,

5. Pencampuran yang cukup dari bahan - bahan pembentuk beton,

6. Penempatan yang benar, penyelesaian dan pemadatan beton,

7. Perawatan beton

8. Kandungan klorida tidak melebihi $0,15 \%$ dalam beton yang diekspos dan $1 \%$ bagi beton yang tidak dieskpos.

\section{Iron Slag}

Iron Slag adalah hasil limbah industri peleburan baja dan sebagian besar mengandung oksida besi, silikat dan kapur serta mempunyai sifat kimia yang stabil dan sifat fisik yang sama dengan pasir.

Beberapa keuntungan panggunaan Slag dalam campuran beton adalah sebagai berikut:

1. Meningkatkan kekuatan beton

2. Meningkatkan ketahanan terhadap sulfat dalam air

3. Mengurangi panas hidrasi dan memperkecil porositas

Slag memiliki bentuk yang tidak beraturan dan memiliki tekstur kasar mendekati runcing, berwarna abu-abu kehitaman (karena memiliki kandungan FeO yang cukup tinggi), mempunyai sifat kimia yang stabil dan sifat fisik yang hampir sama dengan pasir alami. Oleh karena itu, Slag lebih banyak digunakan sebagai pengganti agregat halus. Namun, Slag juga dapat dimanfaatkan sebagai pengganti sebagian semen tetapi materialnya harus dihaluskan hampir seperti semen agar didapatkan hasil yang optimum.

Adapun hasil pengujian karakteristik iron slag yang diperoleh dari hasil 
pengujian laboratorium seperti yang terlihat pada tabel 1 .

\section{Superplasticizer}

Superplasticizer adalah zat-zat polymer organik yang dapat larut dalam air yang telah dipersatukan dengan menggunakan proses polymerisasi yang komplek untuk menghasilkan molekulmolekul panjang dari massa molecular yang tinggi.

Tabel 1. Pemeriksaan Karakteristik Iron Slag.

\begin{tabular}{|c|c|c|c|}
\hline No & Karakteristik & Hasil & Spesifikasi \\
\hline 1 & Kadar Lumpur & $5.98 \%$ & $0.2-6.0 \%$ \\
\hline 2 & Kadar Air & $4.68 \%$ & $3.0 \%-5.0 \%$ \\
\hline 3 & Berat Isi & 1.56 & $\begin{array}{c}1,4-1,9 \\
\mathrm{gr} / \mathrm{cm}^{3}\end{array}$ \\
\hline 4 & Absorpsi & $4.0 \%$ & $0.2-2 \%$ \\
\hline 5 & Berat Jenis SSD & 3.19 & $1.6-3.2$ \\
\hline & $\begin{array}{l}\text { Imber: Hasil P } \\
\text { a Tangke Datu, } \\
\text { Molekul-molek } \\
\text { mbungkus diri } \\
\text { nen dan membe } \\
\text { g tinggi sehing } \\
\text { n saling menj } \\
\text { akan menim } \\
\text { tikel semen se } \\
\text { nceran aduka } \\
\text { rkabilitas. Perb } \\
\text { at dimanfaatka } \\
\text { on dengan wo } \\
\text { u menghasilka } \\
\text { an yang tinggi. }\end{array}$ & $\begin{array}{l}\text { ujian } L \\
\text { 19) } \\
\text { panjan } \\
\text { nengelili } \\
\text { kan pens } \\
\text { antar pa } \\
\text { i dan m } \\
\text { lkan p } \\
\text { lgga me } \\
\text { dan m } \\
\text { kan wor } \\
\text { untuk m } \\
\text { ability } \\
\text { beton }\end{array}$ & $\begin{array}{l}\text { boratorium } \\
\text { ini akan } \\
\text { gi partikel } \\
\text { aruh negatif } \\
\text { tikel semen } \\
\text { enolak. Hal } \\
\text { ndispersian } \\
\text { agakibatkan } \\
\text { ningkatkan } \\
\text { abilitas ini } \\
\text { enghasilkan } \\
\text { ang tinggi } \\
\text { engan kuat }\end{array}$ \\
\hline
\end{tabular}

\section{Workability}

Salah satu sifat beton sebelum mengeras (beton segar) adalah kemudahan pengerjaan (workability). Workability adalah tingkat kemudahan pengerjaan beton dalam mencampur, mengaduk, menuang dalam cetakan dan pemadatan tanpa mengurangi homogenitas beton dan beton tidak mengalami bleeding (pemisahan) yang berlebihan untuk mencapai kekuatan beton yang diinginkan.

Menurut Kardiyono Tjokrodimuljo (1996), unsur-unsur yang mempengaruhi sifat workability antara lain adalah berikut ini:

1. Jumlah air yang dipakai dalam campuran adukan beton, makin banyak air yang dipakai makin mudah beton segar ini dikerjakan.

2. Penambahan semen ke dalam campuran juga memudahkan cara pengerjaan adukan betonnya, karena pasti diikuti dengan bertambahnya air campuran untuk memperoleh nilai fas tetap.

3. Gradasi campuran pasir dan kerikil, bila campuran pasir dan kerikil mengikuti

gradasi yang telah disarankan oleh peraturan maka adukan beton akan mudah dikerjakan.

4. Pemakaian butir-butir batuan yang bulat mempermudah cara pengerjaan beton.

5. Pemakaian butir maksimum kerikil yang dipakai juga berpengaruh terhadap

tingkat kemudahan pengerjaan.

6. Cara pemadatan adukan beton menetukan sifat pengerjaan yang berbeda. Bila cara pemadatan dilakukan dengan alat getar maka diperlukan tingkat kelecakan yang berbeda, sehingga diperlukan jumlah air yang lebih sedikit jika dipadatkan dengan tangan.

\section{Kuat Tekan Beton}

Kekuatan tekan beton diwakili dengan tegangan tekan maksimum fc' dengan satuan N/mm2 atau $\mathrm{MPa}$ dan juga memakai satuan $\mathrm{kg} / \mathrm{cm} 2$. Kekuatan tekan beton merupakan sifat yang paling penting dari beton keras. Umumnya kuat tekan beton berkisar antara nilai 10-65 MPa. Untuk struktur beton bertulang pada umumnya menggunakan kuat tekan pada umur 28 hari berkisar 17-35 $\mathrm{MPa}$, untuk beton prategang digunakan beton dengan kuat tekan lebih tinggi, berkisar antara 30-45 $\mathrm{MPa}$

Kekuatan tekan merupakan salah satu kinerja utama beton. Kekuatan tekan 
adalah kemampuan beton untuk menerima gaya tekan per satuan luas (Mulyono, 2003). Kuat tekan beton dapat dihitung dengan rumus :

Keterangan :

$$
f^{\prime} c=\frac{P}{A}
$$

$\mathrm{f}^{\prime} \mathrm{c}=$ kuat tekan beton $(\mathrm{MPa})$

$\mathrm{P}=$ beban tekan $(\mathrm{N})$

$\mathrm{A}=$ luas permukaan benda uji $\left(\mathrm{mm}^{2}\right)$

\section{METODE PENELITIAN}

\section{Lokasi Penelitian}

Metode yang digunakan dalam penelitian ini adalah metode eksperimental. Pemecahan masalah pada penelitian ini dengan menggunakan cara statistik, yaitu dengan urutan kegiatan dalam memperoleh data, data itu berguna sebagai dasar pembuatan keputusan diantaranya melalui proses pengumpulan data, pengolahan, analisis data, dan cara pengambilan keputusan secara umum berdasarkan hasil penelitian.

Material yang digunakan dalam penelitian ini adalah semen PCC, pasir, batu pecah, dan Iron slag sebagai pengganti agregat halus slag yang berasal dari pabrik PT. Barawaja yang beroperasi di Makassar, Sulawesi Selatan. Agregat yang digunakan dilakukan analisis properties terlebih dahulu untuk memperoleh karakteristik material, selanjutnya dibuat rancangan campuran beton.

Dari hasil rancangan campuran dibuat benda uji berupa silinder. Benda uji dibuat dalam 2 (dua) tipe yaitu: beton normal (beton kontrol) dan beton dengan Iron slag. Iron slag digunakan sebagai material substitusi agregat halus dengan memvariasikan kadarnya dalam campuran beton.

Selanjutnya dalam penelitian ini yang merupakan variabel bebas adalah variasi substitusi Iron Slag dengan kadar 0\%, $75 \%$ dan $100 \%$ dari jumlah agregat halus. Sedangkan variabel terikatnya adalah penggunaan zat admixture
Superplasticizer sebanyak 1\%. Variabel benda uji dapat dilihat pada tabel 2 .

Teknik pengumpulan data dengan cara melakukan pengujian kuat tekan beton dengan menggunakan mesin Compression Testing Machine sampai silinder mencapai kekuatan batas. Data yang terkumpul digunakan untuk menganalisis karakteristik beton yang menggunakan Iron slag.

\section{HASIL PENELITIAN}

\section{Pengujian Slump Test}

Pengujian nilai slump menggunakan kerucut Abrams dengan ukuran diameter atas $10 \mathrm{~cm}$, diameter bawah $20 \mathrm{~cm}$ dan tinggi $30 \mathrm{~cm}$ seperti yang terlihat pada Gambar 1. Pengujian ini dilakukan pada setiap adukan beton dengan substitusi pasir sebesar 0\%, $75 \%$ dan $100 \%$. Hasil pengujian slump test untuk berbagai proporsi campuran dapat dilihat pada tabel 3.

Workability (kemudahan pengerjaan) beton dapat dilihat dari slump yang terjadi. Semakin tinggi nilai slump maka semakin mudah pengerjaan beton (Workable). Dari hasil penelitian menunjukkan bahwa nilai slump meningkat seiring bertambahnya persentase slag dalam campuran beton, seperti yang ditunjukkan pada Gambar 2.

Tabel 2. Variasi Benda Uji.

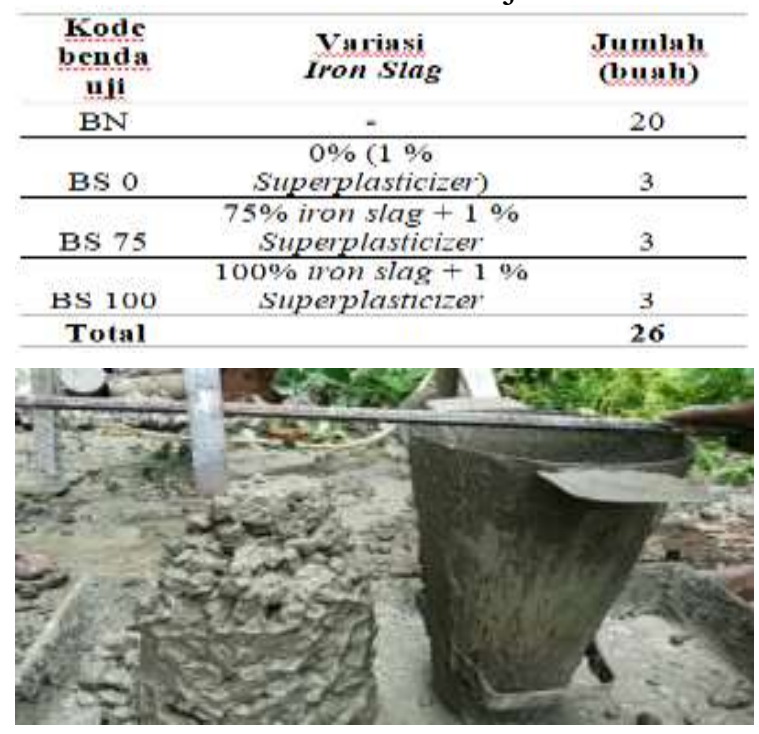

Gambar 1. Pengujian Slump Test 
Tabel 3. Kondisi Slump berbagai Proporsi Campuran

\begin{tabular}{cccc}
\hline No. & $\begin{array}{c}\text { Variasi } \\
\text { Iron Slag }\end{array}$ & $\begin{array}{c}\text { Jumlah } \\
\text { Sampel(bh) }\end{array}$ & $\begin{array}{c}\text { Slump } \\
\text { (mm) }\end{array}$ \\
\hline 1 & BN & 20 & 87 \\
\hline 2 & BS 0 & 3 & 82 \\
\hline 3 & BS 75 & 3 & 70 \\
\hline 4 & BS 100 & 3 & 68 \\
\hline
\end{tabular}

Sumber: Hasil Pengamatan Laboratorium

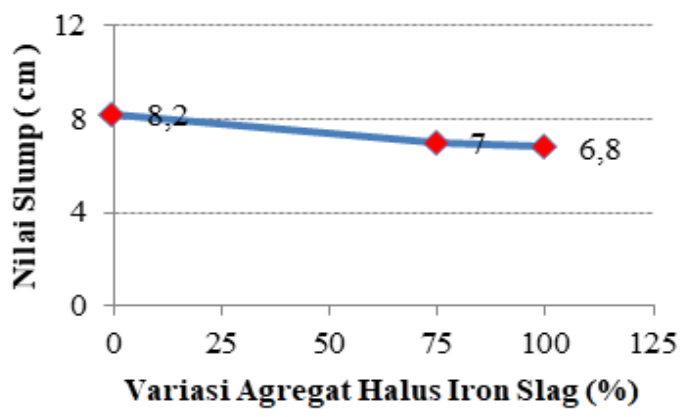

Gambar 2. Grafik Hubungan Nilai Slump dari berbagai variasi Iron Slag

\section{Kuat Tekan Beton Normal}

Tabel 4. Hasil Pengujian Kuat Tekan Beton Normal

\begin{tabular}{|c|c|c|c|}
\hline \multirow{2}{*}{$\begin{array}{c}\text { Kode } \\
\text { Sampel }\end{array}$} & \multirow{2}{*}{$\begin{array}{c}\text { No } \\
\text { Benda } \\
\text { Uji }\end{array}$} & $\begin{array}{c}\text { Beban } \\
\text { Maksimum }\end{array}$ & $\begin{array}{c}\text { Kekuatan } \\
\text { Tekan }\end{array}$ \\
\hline & & $(\mathrm{KN})$ & (Мра) \\
\hline \multirow{20}{*}{$\mathrm{BN}$} & 1 & 383 & 21.68 \\
\hline & 2 & 415 & 23.50 \\
\hline & 3 & 384 & 21.74 \\
\hline & 4 & 386 & 21.85 \\
\hline & 5 & 432 & 24.46 \\
\hline & 6 & 380 & 21.51 \\
\hline & 7 & 385 & 21.80 \\
\hline & 8 & 380 & 21.51 \\
\hline & 9 & 385 & 21.80 \\
\hline & 10 & 365 & 20.67 \\
\hline & 11 & 390 & 22.08 \\
\hline & 12 & 410 & 23.21 \\
\hline & 13 & 386 & 21.85 \\
\hline & 14 & 395 & 22.36 \\
\hline & 15 & 430 & 24.35 \\
\hline & 16 & 410 & 23.21 \\
\hline & 17 & 380 & 21.51 \\
\hline & 18 & 395 & 22.36 \\
\hline & 19 & 380 & 21.51 \\
\hline & 20 & 395 & 22.36 \\
\hline \multicolumn{3}{|c|}{ Kuat tekan rata-rata } & 22.27 \\
\hline
\end{tabular}

Sumber: Hasil Pengujian Laboratorium $\mathrm{fck}=\mathrm{fcm}-\mathrm{k} \times \mathrm{S}$ fck $=22,27-1,64(0,94 \times 1,08)$ fck $=20.51 \mathrm{Mpa}>20 \quad \mathrm{Mpa}$
Kuat tekan adalah besarnya beban persatuan luas, yang menyebabkan benda uji hancur bila dibebani dengan gaya tekan tertentu, yang dihasilkan oleh mesin uji. Kuat tekan beton ditentukan oleh perbandingan semen dan agregat halus, agregat kasar dan air dari berbagai jenis campuran. Perbandingan air terhadap semen merupakan faktor utama dalam penentuan kuat tekan beton. Nilai kuat tekan beton normal dapat dilihat pada tabel 4 .

\section{Pengaruh Superplasticizer terhadap Kuat Tekan Beton}

Gambar 5 menunjukkan grafik perbandingan kuat tekan beton normal dengan beton yang menggunakan superplasticizer, dimana kuat tekan beton yang menggunakan Superplasticizer mengalami peningkatan sebesar 1, $84 \%$ terhadap beton yang tidak menggunakan Superplasticizer. Sehingga dapat disimpulkan bahwa penambahan Superplasticizer dapat dimanfaatkan untuk menghasilkan beton dengan workability yang tinggi atau menghasilkan beton dengan kuat tekan yang tinggi.

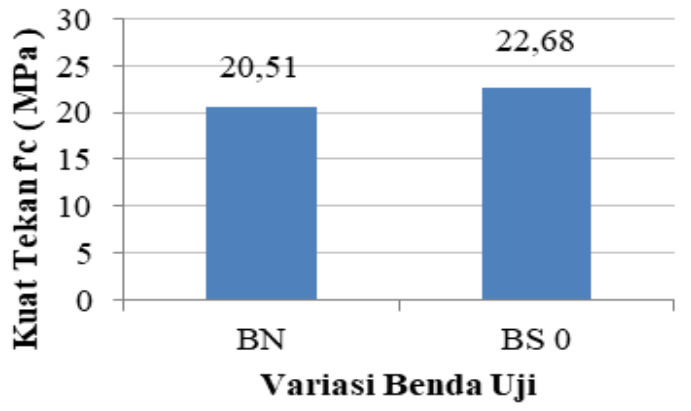

Gambar 3. Grafik Perbandingan Kuat Tekan Beton Normal dengan Beton yang Menggunakan Superplasticizer

\section{Pengaruh Variasi Iron Slag terhadap Kuat Tekan Beton}

Dari hasil penelitian menunjukkan bahwa semakin besar kadar Iron Slag yang digunakan pada campuran beton, maka nilai kuat tekan beton akan 
semakin meningkat, hal tersebut ditunjukkan pada tabel 5 .

Tabel 5. Hasil Pengujian Kuat Tekan Beton Variasi

\begin{tabular}{|c|c|c|c|c|}
\hline \multirow[t]{2}{*}{$\begin{array}{c}\text { Kode } \\
\text { Sampel }\end{array}$} & \multirow{2}{*}{$\begin{array}{c}\text { No } \\
\text { Ben } \\
\text { da } \\
\text { Uji }\end{array}$} & \multirow{2}{*}{$\begin{array}{c}\begin{array}{c}\text { Beban } \\
\text { Max }\end{array} \\
(\mathbf{K N})\end{array}$} & \multirow{2}{*}{$\begin{array}{c}\text { Kuat } \\
\text { Tekan } \\
\text { Mpa) }\end{array}$} & \multirow{2}{*}{$\begin{array}{c}\text { Kenaikan } \\
\text { Kuat } \\
\text { Tekan } \\
(\%)\end{array}$} \\
\hline & & & & \\
\hline \multirow{4}{*}{ BS 0} & 1 & 395.3 & 22.38 & \multirow{4}{*}{1.84} \\
\hline & 2 & 417.8 & 23.65 & \\
\hline & 3 & 388.7 & 22.01 & \\
\hline & \multicolumn{2}{|c|}{ Rata-rata } & 22.68 & \\
\hline \multirow{4}{*}{ BS 75} & 1 & 575.4 & 32.58 & \multirow{4}{*}{47.32} \\
\hline & 2 & 594.7 & 33.67 & \\
\hline & 3 & 568.3 & 32.18 & \\
\hline & \multicolumn{2}{|c|}{ Rata-rata } & 32.81 & \\
\hline \multirow{4}{*}{ BS 100} & 1 & 635.5 & 35.98 & \multirow{4}{*}{10.88} \\
\hline & 2 & 643.6 & 36.44 & \\
\hline & 3 & 648.4 & 36.71 & \\
\hline & \multicolumn{2}{|c|}{ Rata-rata } & 36.38 & \\
\hline
\end{tabular}

Sumber : Hasil Pengujian Laboratorium

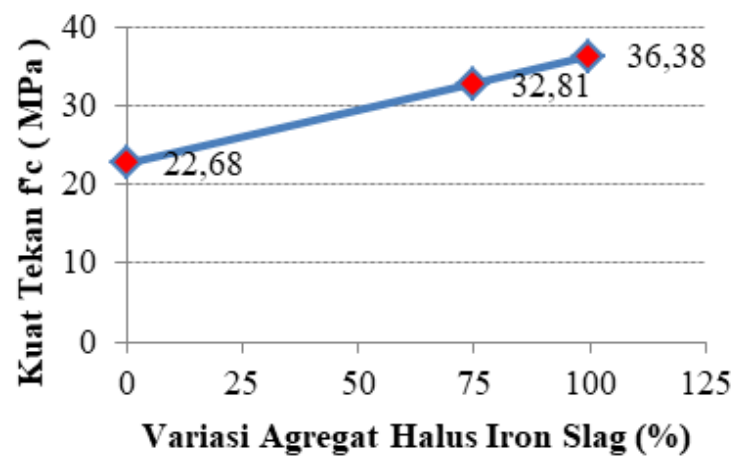

Gambar 4. Grafik Hubungan Kuat Tekan Beton Rata-rata dengan Variasi Iron Slag.

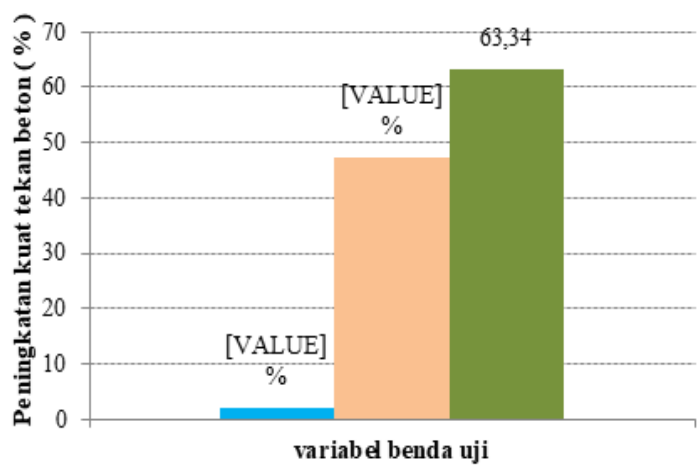

Gambar 5. Grafik persentase peningkatan kuat tekan beton variasi terhadap beton normal.

Gambar 4 memperlihatkan bahwa kuat tekan rata-rata beton pada umur 28 hari diperoleh masing-masing benda uji BS 0 sebesar 22,68 $\mathrm{MPa}$, benda uji BS 75 sebesar 32,81 MPa dan benda uji BS 100 sebesar 36,38 MPa. Hal ini menunjukkan bahwa prosentase penambahan Iron Slag ke dalam matriks beton dapat meningkatkan kuat tekan. Peningkatan kuat tekan ini dipengaruhi oleh adanya kontribusi Iron slag yang membantu beton dalam menahan beban.

Sedangkan gambar 5 menunjukkan hasil perhitungan prosentase kenaikan kuat tekan beton berdasarkan prosentase penambahan Iron Slag diperoleh masingmasing benda uji BS 0 meningkat $1,84 \%$, benda uji BS 75 meningkat 47,32\% dan benda uji BS 100 sebesar 63,34\%. Hal ini menunjukkan bahwa penambahan Iron Slag pada BS 100 merupakan prosentase penambahan Iron Slag yang optimal karena dapat memberikan kenaikan kuat tekan yang signifikan dengan penggunaan Iron Slag terkecil. Sehingga dapat disimpulkan bahwa Iron Slag memenuhi kriteria sebagai material alternatif pengganti sebagian agregat halus pada campuran beton.

\section{KESIMPULAN}

Kesimpulan yang diperoleh dalam penelitian ini adalah sebagai berikut:

1. Peningkatan kuat tekan beton variasi yang tertinggi terjadi pada benda uji BS 100 yaitu sebesar sebesar $63,34 \%$ terhadap beton normal (beton kontrol)..

2. Penggunaan Iron Slag sebagai material pengganti sebagian agregat halus pada campuran beton dapat meningkatkan kemampuan beton dalam menahan beban.

\section{UCAPAN TERIMA KASIH}

Penulis mengucapkan terima kasih kepada DRPM Ristek DIKTI atas bantuan dana Hibah Penelitian Dosen Pemula dan seluruh civitas akademika Universitas Bosowa atas dukungannya selama kegiatan penelitian ini berlangsung. Selain itu, kami juga 
mengucapkan terima kasih kepada pengelola Laboratorium Struktur dan Bahan Beton Jurusan Teknik Sipil Universitas Bosowa atas bantuan dan kerjasamanya.

\section{DAFTAR PUSTAKA}

Adiwijaya, Tangke Datu Irka, Khairil, 2018, Penerapan Slag Baja Sebagai Pengganti Agregat Pada Karakteristik Self Compacting Concrete, Prosiding Seminar Hasil Penelitian (SNP2M) 2018 (pp.166-171), Politeknik Negeri Ujung Pandang, Makassar.

Arief Purnomo, Febry., 2012, Tinjauan Kuat Tekan Dan Modulus Elastisitas

Beton Dengan Variasi Kadar Slag dan Aktivator Sebagai Pengganti Sebagian Semen, Universitas Sebelas Maret, Surakarta.

Hanif, 2012, Penggunaan Steel Slag dengan Variasi FAS terhadap Kuat Tekan Beton. Jurnal Ilmu Pengetahuan dan Teknologi Terapan, REINTEK. Vol.7, No.2.Tahun 2012. ISSN 19075030. Politeknik Negeri Lhokseumawe.

Moenir Misbachul, Irnaning Handayani Novarina, 2012, Recycling Limbah Padat Industri Peleburan Besi (Iron Slag) Sebagai Bahan Campuran Industri Beton yang Berwawasan Lingkungan. Jurnal Riset Teknologi Pencegahan Pencemaran Industri. ISSN 20870965. Balai Besar Teknologi Pencegahan Pencemaran Industri, Semarang.

Tangke Datu, Irka., 2013, Karakteristik Mekanis Beton Mutu Tinggi Polypropylene Fiber yang Menggunakan Limbah Slag Baja Sebagai Agregat Kasar, Seminar Nasional III Teknik Sipil 2013,
Universitas Muhammadiyah Surakarta.

Tangke Datu, Irka., 2019, Evaluasi Pemanfaatan Limbah Slag Baja Sebagai Agregat Halus Pada Produksi Beton Mutu Tinggi, Prosiding Seminar Nasional Penelitian \& Pengabdian Kepada Masyarakat 2019 (pp.119-123), 978-602-60766-7-0. 